\title{
The Buffer Values and the Bohr Effect of Human Fetal and Adult Whole Blood in Vitro in an Acid Range
}

\author{
Wanda Arczynska And L. S. Prod'hom ${ }^{[29]}$ \\ Service de Pédiatrie, Hôpital Cantonal Universitaire, Lausanne, Switzerland
}

\section{Extract}

The buffering properties and the Bohr effect were studied in vitro on 10 human fetal and 9 adult whole blood samples. At the beginning of the experiments, the fetal and adult blood samples were similarly acidotic $(B E=-9 \mathrm{mEq} / \mathrm{liter})$.

In order to obtain the respiratory and the metabolic buffer values, the blood was titrated either by varying the $\mathrm{P}_{\mathrm{CO}_{2}}$ at constant buffer base or by adding known amounts of base at constant $\mathrm{P}_{\mathrm{CO}_{2}}$. The mean fetal and adult in vitro apparent respiratory buffer values $\left(\beta^{\prime}\right)$ were $28.30 \mathrm{mEq} \mathrm{HCO}_{3}-$ liter $\cdot \mathrm{pH}$ unit \pm 2.23 SEM and $23.66 \mathrm{mEq} \mathrm{HCO}_{3}-/$ liter $\cdot \mathrm{pH}$ unit $\pm 0.80 \mathrm{SEM}$, respectively. These values were not statistically different. The in vitro apparent metabolic buffer value $(\lambda)$ rose significantly when $\mathrm{P}_{\mathrm{CO}_{2}}$ increased. At $\mathrm{P}_{\mathrm{CO}_{2}}$ of 30,40 , and $60 \mathrm{~mm} \mathrm{Hg}$, the mean values were, respectively, for fetal blood: $55 \pm 1.75 \mathrm{SEM}, 61.25 \pm 1.41 \mathrm{SEM}$, and $71.25 \pm 3.21$ SEM $\mathrm{mEq} \mathrm{H} \mathrm{H}^{+} /$liter $\cdot \mathrm{pH}$ unit; for adult blood: $61.94 \pm 2.76$ SEM, $65.83 \pm 2.47$ SEM, and $71.94 \pm 2.97 \mathrm{sEM} \mathrm{mEq} \mathrm{H}^{+} /$liter $\cdot \mathrm{pH}$ unit. Only at a $\mathrm{P}_{\mathrm{CO}_{2}}$ of $30 \mathrm{~mm} \mathrm{Hg}$ was the difference between adult and fetal blood statistically significant. In order to determine the magnitude of the Bohr effect, the iso- $\mathrm{P}_{\mathrm{CO}_{2}} \mathrm{pH}$ change $\left(\Delta \mathrm{pH}_{\mathrm{ox}}\right)$ associated with the oxygenation of a desaturated blood sample was measured and the $\mathrm{O}_{2}$ contents were determined by Natelson's micromanometric method. Thus, by the following equation: $\Delta \mathrm{H}^{+}=\lambda \cdot \Delta \mathrm{pH}$, the ratio $-\Delta \mathrm{H}^{+} / \Delta \mathrm{O}_{2}$ was calculated. The mean values obtained for $\mathrm{P}_{\mathrm{CO}_{2}}$ of 30,40 , and $60 \mathrm{~mm} \mathrm{Hg}$ were, respectively, $0.330 \pm 0.027$ SEM, $0.365 \pm 0.028 \mathrm{sEM}$, and $0.401 \pm 0.032 \mathrm{sEM} \mathrm{mEq} \mathrm{H}^{+} / \mathrm{mM} \mathrm{O}_{2}$ for fetal blood; and $0.391 \pm 0.029 \mathrm{sEM}, 0.414 \pm 0.029 \mathrm{sEM}$ and $0.445 \pm 0.032 \mathrm{sEM} \mathrm{mEq} \mathrm{H}+/ \mathrm{mM} \mathrm{O}_{2}$ for adult blood. No significant differences were found at each $\mathrm{P}_{\mathrm{CO}_{2}}$ between the adult and the fetal blood.

\section{Speculation}

These results show that the in vitro buffering properties and the Bohr effect were similar in the adult and the fetal whole blood. The observed difference between the adult and fetal blood for the metabolic buffer value at $\mathrm{P}_{\mathrm{CO}_{2}}$ of $30 \mathrm{~mm} \mathrm{Hg}$ could be explained by differences in hemoglobin $(\mathrm{Hb})$ concentration or different carbamino reaction with fetal hemoglobin $(\mathrm{HbF})$. However, the heterogeneity and the complexity of whole blood hinder simple interpretation. The practical implication of this study is that the use of the Siggaard-Andersen's nomogram for fetal blood is justified, at least in vitro. 


\section{Introduction}

It is often assumed that fetal blood has the same fundamental acid-base properties as adult blood; for instance, the acid-base status of fetal or neonate blood is usually determined by using Siggaard-Andersen's nomogram, although this nomogram was constructed from values of adult blood [17, 19]. However, comparing fetal and adult blood, physicochemical differences, such as the higher hemoglobin concentration, the presence of fetal hemoglobin, or lower fetal protein concentration could result in different buffering properties for fetal blood. Furthermore, when partly desaturated blood is analyzed by the Astrup method, a correction depending on the Bohr effect must be introduced [18, 19]. The magnitude of this correction could also be modified by the possible fetal buffering pecularities or the $\mathrm{HbF}$ properties. Thus, this study was undertaken in order to evaluate the properties of the fetal blood buffers and the magnitude of the fetal Bohr effect in comparison with adult blood.

The in vitro buffering properties of blood were studied by measuring the respiratory and metabolic buffer values. According to the data of Van Slyke [22], the buffer value, $\mathrm{dB} / \mathrm{dpH}$, represents the amount of added base, $\mathrm{dB}$, causing a $\mathrm{pH}$ change, $\mathrm{dpH}$, in 1 liter of solution. This concept can be used in the titration of whole blood, although there are more complicated relationships than in simple buffer solutions. As a consequence of this complexity, the buffer values measured in whole blood are empiric and can be called apparent buffer values. Thus, the in vitro titration of blood with addition or release of carbonic acid by changing the $\mathrm{P}_{\mathrm{CO}_{2}}$ at constant buffer base permits the calculation of the apparent respiratory buffer value $\left(\beta^{\prime}\right)=$ $-\triangle \mathrm{HCO}_{3}-/ \Delta \mathrm{pH}$, whereas the in vitro titration at constant $\mathrm{P}_{\mathrm{CO}_{2}}$ by varying the buffer base gives the apparent metabolic buffer value $(\lambda)=-\Delta \mathrm{H}^{+} / \Delta \mathrm{pH}$. As described by Wyman (24), the linkage of $\mathrm{O}_{2}$ and $\mathrm{H}+$ by the $\mathrm{Hb}$ molecule can be expressed either as the ratio $-\Delta \mathrm{H}^{+} / \Delta \mathrm{O}_{2}$ for a given $\mathrm{pH}$, or as the ratio $\Delta \log \mathrm{P}_{\mathrm{O}_{2}} /$ $\Delta \mathrm{pH}$ for a given $\mathrm{O}_{2}$ saturation level. Many authors have studied and compared this last expression of the Bohr effect for fetal and adult blood, but the results are inconsistent. Some found lower values for adult $(0.45)$ than for fetal blood $(0.60)$, others obtained higher values for adult $(0.50)$ than for fetal blood $(0.41)[8,9]$. Besides, Kirschbaum found, for fetal blood, values from 0.46 to 0.57 , depending on the $\mathrm{O}_{2}$ saturation [12]. These experiments were usually made by varying the $\mathrm{P}_{\mathrm{CO}_{2}}$ in order to change the $\mathrm{pH}$. However, it has re- cently been proved that both $\mathrm{pH}$ and $\mathrm{P}_{\mathrm{CO}_{2}}$ influence independently the magnitude of the Bohr effect $[1,2$, 20]. In this study, the $-\Delta \mathrm{H}+/ \Delta \mathrm{O}_{2}$ ratio was chosen as an expression of the Bohr effect and it was measured for fetal and adult whole blood at constant $\mathrm{P}_{\mathrm{CO}_{2}}$ and well defined acid-base conditions.

Our results show that the in vitro respiratory buffer value and the Bohr effect were similar for adult and fetal blood at least in the range of $\mathrm{P}_{\mathrm{CO}_{2}}$ and $\mathrm{pH}$ studied. The in vitro metabolic buffer value was also similar for adult and fetal bloods at $\mathrm{P}_{\mathrm{CO}_{2}}$ of 40 and $60 \mathrm{~mm}$ $\mathrm{Hg}$, but dependent on the $\mathrm{P}_{\mathrm{CO}_{2}}$. However, at $\mathrm{P}_{\mathrm{CO}_{2}}$ of 30 $\mathrm{mm} \mathrm{Hg}$ it was significantly lower for the fetal than for the adult blood.

\section{Methods}

The method was thoroughly described in a previous paper (1) and only a few specific points will be mentioned.

\section{Principle}

The apparent metabolic buffer value $(\lambda)$ was found by in vitro titration of saturated whole blood with known amounts of base and by determining the corresponding iso- $\mathrm{P}_{\mathrm{CO}_{2}} \mathrm{pH}$ shifts. Titration curves could be drawn at any constant $\mathrm{P}_{\mathrm{CO}_{2}}$ and their slopes, $\lambda=$ $-\Delta \mathrm{H}^{+} / \Delta \mathrm{pH}$ were calculated.

The apparent respiratory buffer value $\left(\beta^{\prime}\right)$ was obtained by measuring the $\mathrm{pH}$ of fully oxygenated blood after in vitro equilibration with known $\mathrm{P}_{\mathrm{CO}_{2}}(\sim 30$ and $60 \mathrm{~mm} \mathrm{Hg}$ ); using the Davenport diagram [5], it was possible to determine graphically the slope $\beta^{\prime}=$ $-\Delta \mathrm{HCO}_{3}-/ \Delta \mathrm{pH}$.

The Bohr effect, $-\Delta \mathrm{H}+/ \Delta \mathrm{O}_{2}$, was determined by measuring the $\mathrm{pH}$ shift, $\Delta \mathrm{pH}_{\mathrm{OS}}$, of a given desaturated blood sample while undergoing oxygenation at constant $\mathrm{P}_{\mathrm{CO}_{2}}$. Since $\Delta \mathrm{pH}_{\mathrm{ox}}=\Delta \mathrm{H}+/ \lambda$, the ratio, $-\Delta \mathrm{H}+/$ $\Delta \mathrm{O}_{2}$, can be calculated when the amount of bound $\mathrm{O}_{2}$ is determined.

\section{Material}

Blood from full term fetuses was obtained at delivery by puncture of a cord vessel before the separation of the placenta. We ascertained the absence of maternal blood by measuring the immunoglobulins in each sample. No IgA was detected, thus excluding contamination by maternal blood. The mean $\mathrm{pH}$ ( \pm SEM) determined at $\mathrm{P}_{\mathrm{CO}_{2}} 40 \mathrm{~mm} \mathrm{Hg}$ after saturation was $7.260 \pm 0.009$. Adult blood was taken by venous punc- 
ture from healthy adults. In order to obtain the same $\mathrm{pH}$ at $\mathrm{P}_{\mathrm{CO}_{2}} 40$ as for the fetal blood, $0.5 \mathrm{ml} 0.3 \mathrm{~N}$ isotonic lactic acid was added to $40 \mathrm{ml}$ adult blood. The mean $\mathrm{pH}$ at $\mathrm{P}_{\mathrm{CO}_{2}} 40$ after saturation was then $7.244 \pm 0.01$.

\section{Techniques}

The following modifications of the previously described method [1] were utilized. [1] Each aliquot of blood was $3 \mathrm{ml}$. [2] The titration solutions contained,

Table I. Fetal blood 1

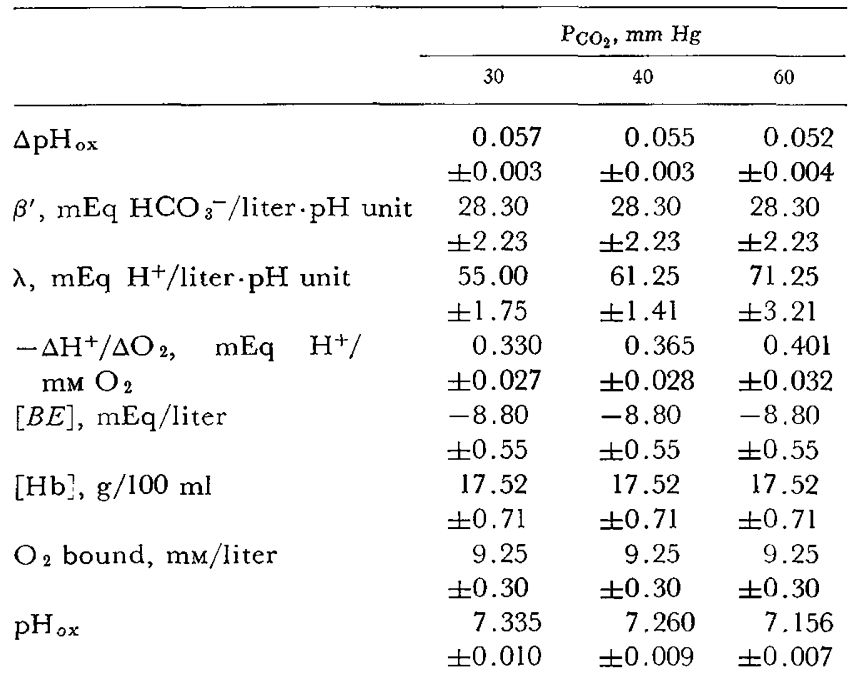

1 Values are expressed as means \pm sem. $N=10$. See text for definition of symbols.

Table II. Adult blood ${ }^{1}$

\begin{tabular}{|c|c|c|c|}
\hline & \multicolumn{3}{|c|}{$\mathrm{P}_{\mathrm{CO}_{2}}, \mathrm{~mm} \mathrm{Hg}$} \\
\hline & 30 & 40 & 60 \\
\hline \multirow[t]{2}{*}{$\Delta \mathrm{pH}_{\mathrm{ox}}$} & 0.053 & 0.052 & 0.051 \\
\hline & \pm 0.005 & \pm 0.004 & \pm 0.004 \\
\hline \multirow[t]{2}{*}{$\beta^{\prime}, \mathrm{mEq} \mathrm{HCO}_{3}-/$ liter $\cdot \mathrm{pH}$ unit } & 23.66 & 23.66 & 23.66 \\
\hline & \pm 0.80 & \pm 0.80 & \pm 0.80 \\
\hline \multirow[t]{2}{*}{$\lambda, \mathrm{mEq} \mathrm{H}^{+} /$liter $\cdot \mathrm{pH}$ unit } & 61.94 & 65.83 & 71.94 \\
\hline & \pm 2.76 & \pm 2.47 & \pm 2.97 \\
\hline \multirow{2}{*}{$\begin{array}{l}-\Delta \mathrm{H}^{+} / \Delta \mathrm{O}_{2}, \quad \mathrm{mEq} \quad \mathrm{H}^{+} / \\
\mathrm{mM} \mathrm{O}_{2} \mathrm{O}_{2}\end{array}$} & 0.391 & 0.414 & 0.445 \\
\hline & \pm 0.029 & \pm 0.029 & \pm 0.032 \\
\hline \multirow[t]{2}{*}[BE]{, $\mathrm{mEq} / \mathrm{liter}$} & -9.37 & -9.37 & -9.37 \\
\hline & \pm 0.52 & \pm 0.52 & \pm 0.52 \\
\hline \multirow[t]{2}{*}[\mathrm{Hb}]{, $\mathrm{g} / 100 \mathrm{ml}$} & 15.82 & 15.82 & 15.82 \\
\hline & \pm 0.27 & \pm 0.27 & \pm 0.27 \\
\hline \multirow[t]{2}{*}{$\mathrm{O}_{2}$ bound, mm/liter } & 8.18 & 8.18 & 8.18 \\
\hline & \pm 0.23 & \pm 0.23 & \pm 0.23 \\
\hline \multirow[t]{2}{*}{$\mathrm{pH}_{\mathrm{ox}}$} & 7.322 & 7.244 & 7.135 \\
\hline & \pm 0.010 & \pm 0.010 & \pm 0.010 \\
\hline
\end{tabular}

${ }^{1}$ Values are expressed as means \pm SEM. $N=9$. See text for definition of symbols. respectively, $0,80,120$, and $160 \mathrm{mEq} /$ liter $\mathrm{NaOH}$ and the amount of $\mathrm{NaCl}$ required for isotonicity. The constant quantity of the solution added to blood was 109 $\mu \mathrm{l}$. [3] Inasmuch as only small amounts of blood were obtainable, the $\mathrm{O}_{2}$ contents could not be measured by Van Slyke's method, and the Natelson microgazometer was chosen. Since the Natelson micromethod used as described either by Holaday and Verosky [10] or by the Instruction booklet no. 5 [14] gave very inconsistent results, the technique was modified (see Appendix). Then the macromethod and the modified micromethod were compared. Eleven comparisons of the macro- and micromethods made on whole blood samples with less than $1 \mathrm{mM} \mathrm{O}_{2}$ /liter showed that the $\mathrm{O}_{2}$ contents obtained by both methods were not statistically different (paired $t$ test: $P>0.5$ ). Eleven analyses of fully oxygenated samples (mean $\mathrm{O}_{2}$ content $8 \mathrm{~mm}$ / liter) showed that the modified Natelson technique gave consistently lower results than Van Slyke's method (paired $t$ test: $P<0.001$ ). The mean difference ( \pm SEM) was $0.52 \mathrm{~mm} /$ liter \pm 0.09 . This quantity was added as a correction factor to each oxygen content obtained for fully saturated blood. This correction factor was not statistically different from that obtained by Holaday and Verosky on five samples in the same range of $\mathrm{O}_{2}$ content $(P>0.5)[10]$.

\section{Results}

Ten experiments were performed with fetal blood and nine with adult blood. Tables I and II summarize the results for fetal and adult blood at $\mathrm{P}_{\mathrm{CO}_{2}}$ of 30,40 , and $60 \mathrm{~mm} \mathrm{Hg}$.

\section{In Vitro Apparent Respiratory Buffer Value $=\beta^{\prime}$}

The adult and fetal $\mathrm{CO}_{2}$ titration curves are shown in Figure 1; their slopes, $\beta^{\prime}$, were not statistically different (Tables I and II, Fig. I).

\section{In Vitro Apparent Metabolic Buffer Value $=\lambda$}

Figure 2 demonstrates, for a $\mathrm{P}_{\mathrm{CO}_{2}}$ of $40 \mathrm{~mm} \mathrm{Hg}$, the relation between the amount of base added and the mean ( \pm sEM) associated $\mathrm{pH}$ shift. As shown on Tables $\mathrm{I}$ and II, $\lambda$ depends markedly on the $\mathrm{P}_{\mathrm{CO}_{2}}$, for either fetal or adult blood. No significant difference was found between fetal and adult $\lambda$ at a $\mathrm{P}_{\mathrm{CO}_{2}}$ of 40 and $60 \mathrm{~mm} \mathrm{Hg}$. But, at a $\mathrm{P}_{\mathrm{CO}_{2}}$ of $30 \mathrm{~mm} \mathrm{Hg}, \lambda$ was significantly lower for fetal than for adult blood $(P<$ 0.05 ). Siggaard-Andersen's base excess scale could be tested by comparing the quantity of base added to the read base excess changes. Figure 3 proves the validity 


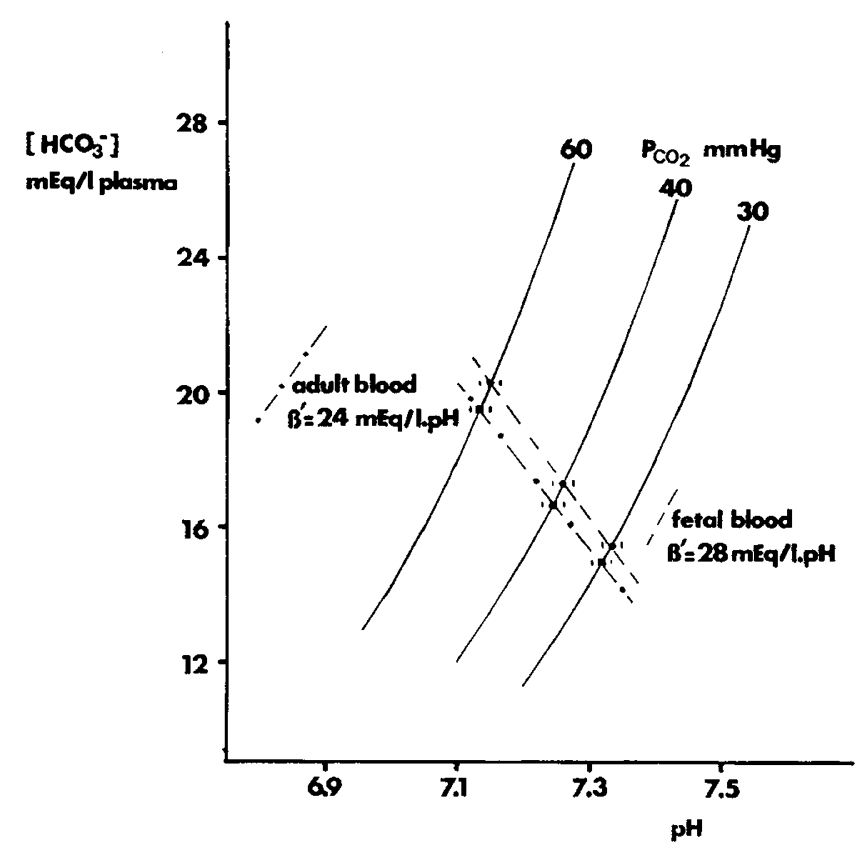

Fig. 1. In vitro $\mathrm{CO}_{2}$ titration curves. $|--|$ : Mean $\mathrm{pH}$ values \pm SEM for adult blood; $|--|$ : mean $\mathrm{pH}$ values \pm SEM for fetal blood.

of this nomogram for fetal blood, at least in the acid $\mathrm{pH}$ range studied.

Bohr Effect $=-\Delta^{+} / \Delta_{2}$

Fetal $-\Delta \mathrm{H}^{+} / \Delta \mathrm{O}_{2}$ ratios did not differ significantly from the ratios for adults, although values obtained from fetal blood were, on the whole, slightly lower than those from adult blood (Tables I and II).

\section{Discussion}

The study of the apparent respiratory and metabolic buffer values makes it possible to evaluate the properties of the noncarbonic and carbonic buffers. Indeed, when whole blood is titrated by varying the $\mathrm{P}_{\mathrm{CO}_{2}}$, i.e., by addition or release of carbonic acid, buffer value $\left(\beta^{\prime}\right)$ depends on the noncarbonic buffer system, chiefly $\mathrm{Hb}$. On the other hand, when whole blood is titrated by an acid or a base at fixed $\mathbf{P}_{\mathrm{CO}_{2}}$, buffer value $(\lambda)$ depends on the noncarbonic and carbonic buffers.

No significant difference was found between the fetal and adult $\beta^{\prime}$, although fetal $\beta^{\prime}$ was on the average higher than adult $\beta^{\prime}$, probably because of the significantly more concentrated $\mathrm{Hb}$ in fetal blood compared with adult blood (Tables I and II). Thus the noncarbonic buffers ( $\mathrm{Hb}$, proteins, phosphates) had on the whole the same buffering effects in fetal as in adult

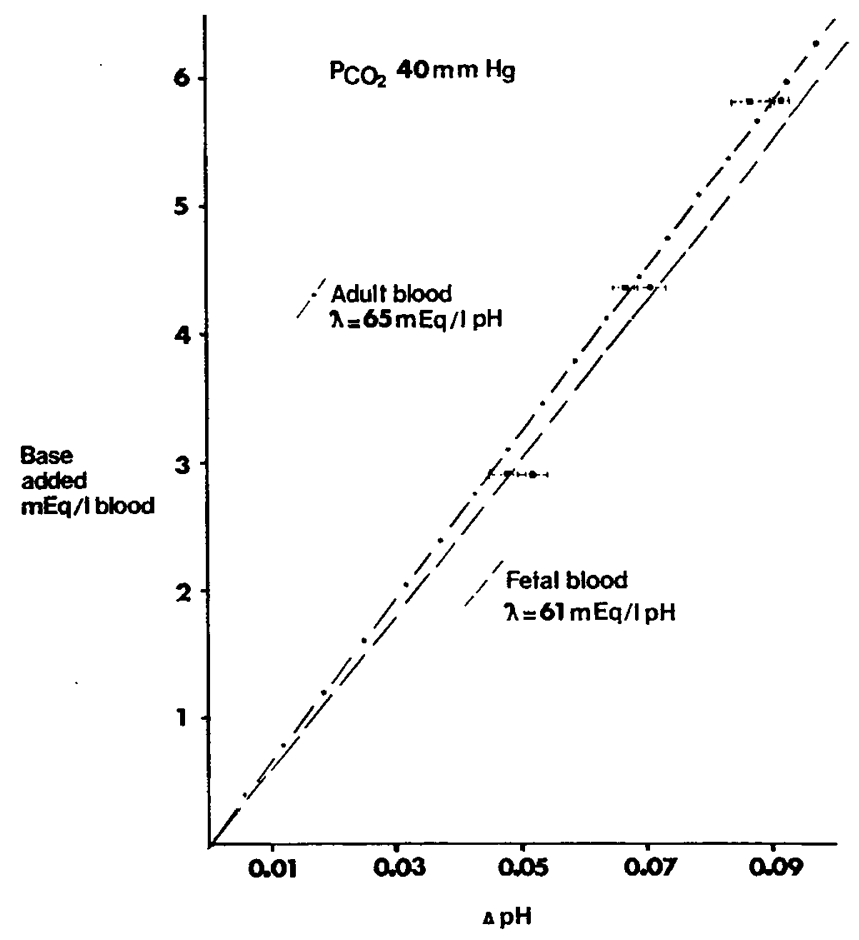

Fig. 2. Mean titration curves of adult and fetal blood at a $\mathbf{P}_{\mathrm{CO}_{2}}$ of $40 \mathrm{~mm} \mathrm{Hg}$. Symbols are the same as in Figure 1.

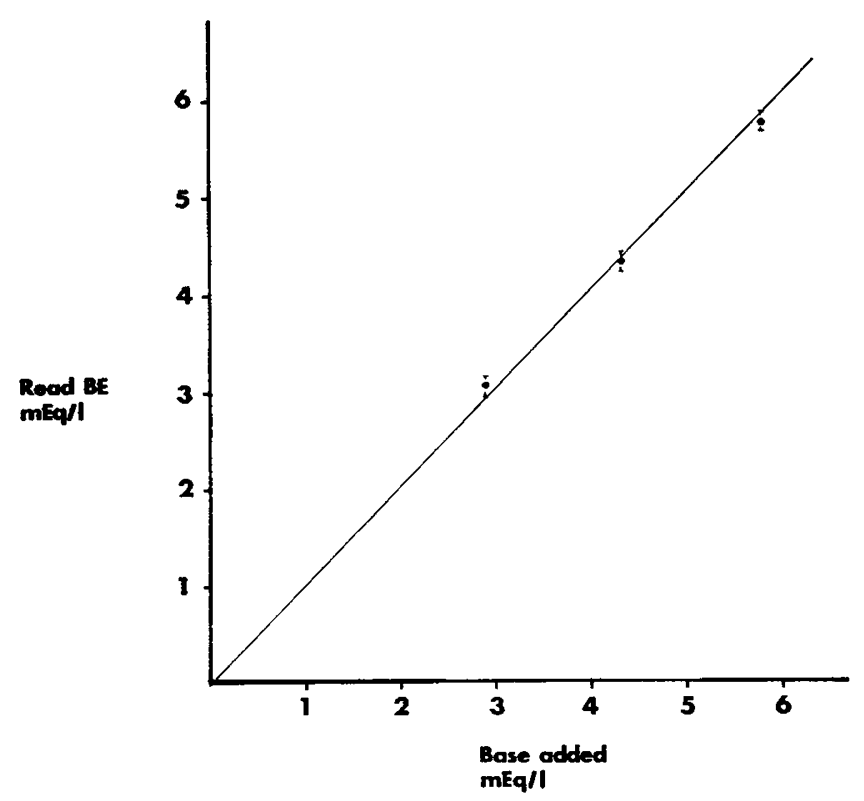

Fig. 3. Relation between the amount of base added and the mean $( \pm$ SEM) read base excess changes for saturated fetal blood.

blood. The metabolic buffer value, $\lambda$, provides an index of the properties of the two buffer systems. The marked increase of $\lambda$ with rising $\mathrm{P}_{\mathrm{CO}_{2}}$ at constant buffer base, either in fetal or adult blood, has pre- 
viously been explained [11]; however, it should be pointed out that when $\mathrm{P}_{\mathrm{CO}_{2}}$ increases, the $\mathrm{HCO}_{3}-$ concentration rises and the metabolic buffer value rises also, according to the special buffer properties of the carbonic system.

Fetal $\lambda$ was significantly lower than adult $\lambda$ at $\mathbf{P}_{\mathrm{CO}_{2}}$ $=30 \mathrm{~mm} \mathrm{Hg}$. However, this discrepancy disappeared at higher $\mathrm{P}_{\mathrm{CO}_{2}}$. Many factors could be responsible for this peculiarity. One can speculate that the fetal whole blood had a lower $\mathrm{HCO}_{3}{ }^{-}$concentration at low $\mathrm{P}_{\mathrm{CO}_{2}}$ than adult blood because of its higher hematocrit, and therefore had a lower carbonic buffer value. Beginning from an identical plasma bicarbonate level at a given $\mathrm{P}_{\mathrm{CO}_{2}}$, the same $\Delta \mathrm{P}_{\mathrm{CO}_{2}}$ would result in a greater $\Delta \mathrm{HCO}_{3}{ }^{-}$in fetal than in adult blood, if fetal $\beta^{\prime}$ was slightly higher than that of adult blood. Thus, at higher $\mathbf{P}_{\mathrm{CO}_{2}}$, the difference of the carbonic buffer value is cancelled and the $\lambda$ would be the same for both fetal and adult blood. Differences in noncarbonic buffers of fetal and adult blood could also be involved. Indeed, in the presence of $\mathrm{CO}_{2}, \mathrm{Hb}$ forms carbamate compounds [7], which increase the buffer power of $\mathrm{Hb}$ [15]. The different structure of $\mathrm{HbF}$, in particular, the - $\mathrm{NH}_{2}$-terminal glycine in $\gamma$ chains instead of the $\mathrm{NH}_{2}$ terminal valine in $\alpha$ chains [16] or peculiarities of the fetal erythrocyte could inhibit this specific action of carbaminos. However, it must be pointed out that all interpretations remain very uncertain because of the complexity of the whole blood system, in which two phases, erythrocytes and plasma, are in equilibrium. This fact and its implications previously discussed [1] must also be considered for the evaluation of the Bohr effect.

Measurements of the Bohr effect on adult ( $\mathrm{HbA})$ and fetal hemoglobin solutions gave a $\Delta \log \mathrm{P}_{\mathrm{O}_{2}} / \Delta \mathrm{pH}$ ratio of 0.48 in both cases [13]. Our values for whole blood are lower than those for $\mathrm{Hb}$ solutions, but were almost identical for fetal and adult blood. The discrepancy between the $\mathrm{Hb}$ solutions and the whole blood has already been discussed for adult blood [1]. A priori, the absence of significant differences between the adult and fetal $-\Delta \mathrm{H}+/ \Delta \mathrm{O}_{2}$ ratios seems surprising in regard to the possible influences of $\mathrm{CO}_{2}$ and 2,3-diphosphoglycerate (2,3-DPG). Indeed, in the case of $\mathrm{HbA}$, the $-\Delta \mathrm{H}^{+} / \Delta \mathrm{O}_{2}$ ratio is decreased by the carbamino reactions [5], but this effect is inhibited by 2,3DPG $[4,20]$. Furthermore, the interaction of 2, 3-DPG and $\mathrm{O}_{2}$ is less marked for $\mathrm{HbF}$ than for $\mathrm{HbA}[3,6,21]$ because of the structural differences of the $\mathrm{HbF}$ molecule. One can assume that the decreasing effect of car- bamino on the Bohr effect of $\mathrm{HbF}$ is not inhibited by 2,3-DPG and, therefore, the $-\Delta \mathrm{H}+/ \Delta \mathrm{O}_{2}$ ratio would be smaller in fetal than in adult blood. It must also be noticed that, although no significant difference was found, fetal values seem to be slightly lower than adult values. Besides, as stated above, $\mathrm{HbF}$ could primarily bind less $\mathrm{CO}_{2}$ than $\mathrm{HbA}$, but no prediction can be made for whole blood because of its complexity. This complexity and the different conditions of measurements mentioned in the Introduction prevents the comparison of our results with those of other authors. According to the data of Wyman [25] and the known effect of $\mathrm{CO}_{2}$ on the Bohr effect, the ratios $\Delta \log \mathrm{P}_{\mathrm{O}_{2}} /$ $\Delta \mathrm{pH}$ and $-\Delta \mathrm{H}^{+} / \Delta \mathrm{O}_{2}$ are identical only when the first ratio is defined for given $\mathrm{O}_{2}$ saturation level and $\mathrm{P}_{\mathrm{CO}_{2}}$, the second one for given $\mathrm{pH}$ and $\mathrm{P}_{\mathrm{CO}_{2}}$. Furthermore, these equations are relevant in the simple situation of $\mathrm{Hb}$ solutions when the possible linkages are known and the medium conditions can be controlled.

It must be emphasized that only empiric values can be measured in whole blood. These values are valid for a given situation of measurement, e.g., in our conditions, at $\mathrm{P}_{\mathrm{CO}_{2}}$ levels of 30 to $60 \mathrm{~mm} \mathrm{Hg}$ and a moderately acidotic state $(B E=-9 \mathrm{mEq} /$ liter $)$. When desaturated fetal blood is analyzed by the Astrup method, it must be kept in mind that the correction for the Bohr effect differs from the values obtained on $\mathrm{Hb}$ solutions and depends on the acid-base condition of the blood.

\section{Summary}

In conclusion, the in vitro respiratory and metaboiic apparent buffer values for the adult and fetal blood are in the same range. This fact is moreover enhanced by the observed validity of the base excess scale for fetal blood in vitro (see Fig. 3). Thus, the use of the Siggaard-Andersen's nomogram is allowable for the fetal blood, with the restriction that the in vitro conditions may not reflect the in vivo state [23].

The theoretical question of the "normality" of the fetus concerning his acid-base status must be considered. Has the fetal or neonate's acid-base status to be regarded as pathologic in comparison with the adult's "normality" or must it be considered as normal when the values are similar to the average observed in the majority of neonates? When it is known that the fundamental in vitro acid-base properties of fetal blood are the same as for adult blood, this question becomes a matter of definition of terms. 


\section{References and Notes}

I. Arczynska, W., And Held, D. R.: The amount of $\mathrm{H}^{+}$released on iso-pH oxygenation of human whole blood. Resp. Physiol., 12: 7 (1971).

2. Baertschi, F., HaAB, P., ANd Held, D. R.: Reliability of blood $\mathrm{P}_{\mathrm{CO}_{2}}$ measurements by the $\mathrm{CO}_{2}$ electrode, the whole blood $\mathrm{C}_{\mathrm{CO}_{2}} / \mathrm{pH}$ method and the Astrup method. Resp. Physiol, 10: 121 (1970).

3. Bauer, C., Ludwig, I., ANd Ludwig, M.: Different effects of 2,3 diphosphoglycerate and adenosine triphosphate on the oxygen affinity of adult and foetal human hemoglobin. Life Sci., 7(1): 1339 (1968).

4. BAUER, C.: Reduction of the carbon dioxide affinity of human haemoglobin solutions by 2,3 diphosphoglycerate. Resp. Physiol., 10: 10 (1970).

5. Davenport, H. W.: The ABC of Acid-Base Chemistry. (The University of Chicago Press, 1958).

6. Duc, G., AND ENGeL, K.: Effect of 2,3 DPG concentration on hemoglobin oxygen affinity of whole blood. Scand. J. Clin. Lab. Invest., 24: 405 (1969).

7. Ferguson, J. K. W.: Carbamino compounds of $\mathrm{CO}_{2}$ with human hemoglobin and their role in the transport of $\mathrm{CO}_{2}$. J. Physiol., 88: 40 (1936).

8. Hellegers, A. E., and Schruefer, J. J. P.: Nomograms and empirical equations relating oxygen tension, percentage saturation, and $\mathrm{pH}$ in maternal and fetal blood. Amer. J. Obstet. Gynccol., $81(I): 377$ (1961).

9. Hilpert, P., Fleischmann, R. G., Kempe, D., and Bartels, H.: The Bohr effect related to blood and erythrocyte $\mathrm{pH}$. Amer. J. Physiol., 205(2): 337 (1963).

10. Holaday, D. A., ANd Verosky, M.: Improved micromanometric methods for the analysis of respiratory gases in plasma and whole blood. J. Lab. Clin. Med. 47: 634 (1956).

11. Karmann, U., Arczynska, W., and Held, D. R., A contribution to the study of the whole blood Bohr effect in the alkaline rangc. Resp. Physiol., 13: 261 (1971).

12. KIrschbaum, T. H.: Variability of magnitude of the Bohr effect in human fetal blood. J. Appl. Physiol., 18 (f): 729 (1963).

13. MANN, L. I., AND Romney, S. L.: The Bohr effect of fetal hemoglobin. Amer. J. Obstet. Gynecol., 101 (2): 520 (1968).

14. Manual for gas determination in blood, plasma, and serum using the Natelson microgasometer. Instruction booklet no. 5 .
15. Rossi-Bernardi, L., and Roughton, F. J. W.: The specific influence of carbon dioxide and carbamate compounds on the buffer power and Bohr effects in human hemoglobin solutions. J. Physiol., 189: I (1967).

16. Schroeder, W. A., Shelton, J. R., Shelton, J. B., Cormick, J., ANd Jones, R. T.: The amino acid sequence of the $\gamma$ chain of human fetal hemoglobin. Biochemistry 2: 992 (1963).

17. Siggaard-Andersen, O.: The pH-log $\mathrm{P}_{\mathrm{CO}_{2}}$ blood acid-base nomogram revised. Scand. J. Clin. Lab Invest., 14: 598 (1962).

18. SigigaArd-Andersen, O.: The Acid-Base Status of the Blood. (Munksgaard, Copenhagen, 1964).

19. SiggaARd-Andersen, O., AND ENGel, K.: A new acid-base nomogram. An improved method for the calculation of the relevant blood acid-base data. Scand. J. Clin. Lab. Invest., 12: 177 (1960).

20. SiggaArd-Andersen, O., ANd Salling, N.: Oxygen linked hydrogen ion binding of human hemoglobin. Effects of carbon dioxide and 2,3 diphosphoglycerate. Scand. J. Clin. Lab. Invest., 27: 351 (1971).

21. Tyuma, I., and Shimizu, K.: Different responses to organic phosphates of human fetal and adult hemoglobins. Arch. Biochem. Biophys., 129: 404 (1969).

22. VAN SLXKE, D. D.: On the measurement of buffer values and on the relationship of buffer value to the dissociation constant of the buffer and the concentration and reaction of the buffer solution. J. Biol. Chem., 52: 525 (1922).

23. Winters, R. W.: Studics of acid-base disturbances. Pediatrics, 39: $700(1967)$.

24. Wyman, J.: Heme proteins. Advan. Protein Chem., 4: 410 (1948).

25. WYMAN, J.: Linked functions and reciprocal effects in hemoglobin: A second look. Advan. Protein Chem., 19: 223 (1964).

26. The authors thank Miss G. Krings for skillful technical assistance.

27. We are indebted to the Department of Physiology of the University of Fribourg, Switzerland, for valuable collaboration and in particular to Professor D. R. Held for helpful advice.

28. This work was supported by Grant no. 3.564.71, Swiss National Foundation for Scientific Research.

29. Requests for reprints should be addressed to: L. S. Prod'hom, M.D., Service de Pédiatrie, Hôpital Cantonal Universitaire, Lausanne, Switzerland.

30. Accepted for publication November 29, 1972.

\section{Appendix}

\section{Modified Natelson's Technique}

Reagents. Saponin-ferricyanid solution $\left(0.4 \mathrm{~g}\right.$ saponin $+1.6 \mathrm{~g} \mathrm{~K}$-ferricyanid, $\mathrm{H}_{2} \mathrm{O}$ to make $50 \mathrm{ml}$. $1 \%$ lactic acid to make $100 \mathrm{ml}$ ); caprylic alcohol; $\mathrm{NaOH}, 3 \mathrm{~N}$; Na-hydrosulfite solution (1 g Na $2 \mathrm{~S}_{2} \mathrm{O}_{4}+5 \mathrm{ml} \mathrm{KOH}, 1 \mathrm{~N}$ ).

All reagents were degassed and kept under vacuum.

Method. Anaerobic introduction of: $0.03 \mathrm{ml}$ blood, $0.01 \mathrm{ml} \mathrm{Hg}, 0.01 \mathrm{ml}$ caprylic alcohol, $0.1 \mathrm{ml}$ saponin-ferricyanid, $0.02 \mathrm{ml}$ caprylic alcohol, $0.1 \mathrm{ml}$ saponin-ferricyanid, $0.01 \mathrm{ml}$ caprylic alcohol, $\mathrm{Hg}$ to the $0.12 \mathrm{ml}$ mark. This was followed by: vacuum + shaking for $5 \mathrm{~min}$, read $\mathrm{P}_{1}$; anaerobic introduction of $0.03 \mathrm{ml} \mathrm{NaOH}, 3 \mathrm{~N}, \mathrm{Hg}$ to the $0.12 \mathrm{ml}$ mark; vacuum + shaking for $3 \mathrm{~min}$, read $\mathrm{P}_{2}$; anaerobic introduction of $0.03 \mathrm{ml} \mathrm{Na}$-hydrosulfite, $\mathrm{Hg}$ to the $0.12-\mathrm{ml}$ mark, vacuum + shaking for 3 min, read $P_{3}$.

The measuring chamber was carefully washed after each measure and the stopcocks regreased.

Blank analyses were made after each two or three measures; blood was replaced with saponin-ferricyanid solution. 